\title{
Elektromobilių panaudojimo plètrą skatinančių priemonių efektyvumo vertinimo modelis
}

\author{
Povilas Mačiulis ${ }^{1}$, \\ Inga Konstantinavičiūtè ${ }^{1}$, \\ Vaida Pilinkiené2, \\ Alina Stundžiené ${ }^{2}$ \\ ${ }^{1}$ Lietuvos energetikos institutas, \\ Breslaujos g. 3, \\ 44403 Kaunas, Lietuva \\ El.paštas Povilas.Maciulis@gmail.com \\ ${ }^{2}$ Kauno technologijos universitetas, \\ K. Donelaičio g. 73, \\ 44249 Kaunas, Lietuva
}

\begin{abstract}
Transporto sektorius turi ypač didelę ịtaką vyriausybèms, siekiančioms dekarbonizacijos tikslų. Tai pirmiausia pasakytina apie kelių transportą. Pagrindinis iššǔkis yra pereiti prie netaršių transporto priemonių, o populiariausia technologija yra elektromobiliai. Nepaisant elektra varomo transporto privalumų ir augančio populiarumo, jų naudojimo plètrą varžo elektromobilių kaina, kuri yra didesnè už ịprastinių automobilių, naudojančių iškastinị kurą. Visos valstybès sprendžia resursų klausimus, todèl labai svarbu išsiaiškinti, kaip galima pasiekti konkrečiu rezultatų su kuo mažesnèmis materialinėmis ir laiko sąnaudomis. Visose šalyse didžią̧ą dalị kelių transporto priemonių parko sudaro privačių asmenų automobiliai. Todèl siekiant ịvertinti atskirų skatinimo priemonių efektyvumą būtina atsižvelgti ne tik ị ekspertų nuomonę, finansinę naudą, tačiau būtina ištirti ir vartotojų preferencijas, kurios gali būti pagrindinis barjeras naujų technologijų panaudojimo plètrai. Mokslinèje literatūroje galima rasti ịvairių elektromobilių naudojimo skatinimo vertinimo būdų, kurie paremti skirtingomis metodologijomis ar jų junginiais. Tačiau vis dar trūksta priemonių efektyvumo vertinimo sistemos, kuri visapusiškai apibendrintų vartotojų preferencijas, iggyvendinamumą, veiksmingumą bei ịvertintų finansinių ir nefinansinių skatinimo priemonių igyvendinimo kaštus. Šio straipsnio tikslas - išanalizuoti elektromobilių naudojimo skatinimo priemonių vertinimo praktiką ir konceptualizuoti skatinimo priemonių efektyvumo vertinimo modelį. Tyrimui naudoti metodai: mokslinès literatūros analizè, sisteminimas ir palyginamoji analizè.
\end{abstract}

Raktažodžiai: elektromobiliai, efektyvumas, skatinimo priemonès

\section{IVADAS}

Elektromobilių technologija visuomenès vertinama kaip turinti itaką energetikos, transporto ir aplinkosaugos sektoriams: elektromobiliai mažina transporto neigiamą poveiki aplinkai, prisideda prie mažesnio iškastinio kuro naudo- jimo ir taip gerina šalių energetinès nepriklausomybès rodiklius [1]. Elektra varomų automobilių rinkos plètra duoda naudą, kuri susijusi su žmonių sveikata, oro kokybe ir aplinka, taip pat ekonomikos augimu $[2,3]$. Be to, elektromobiliai tapo tiesiog patogia alternatyva iprastinèms transporto priemonèms, o pokyčiai šioje 
rinkoje lemia besikeičiančius vartotojų poreikius ir lūkesčius [4]. Dèl elektromobilių sukuriamo poveikio ir augančio populiarumo visuomenèje elektromobilių naudojimo ir jų plettros problematika taip pat kelia vis didesni mokslininkų susidomejjimą.

Nepaisant visų privalumų, techninès ir ekonominès aplinkybès dar neleidžia elektromobilių masinès plètros bendroje transporto priemonių rinkoje [5]. Viena iš priežasčių, kodèl natūralus elektromobilių atėjimas ỉ rinką yra lètas, tai jų kaina, kuri yra didesnè už itprastinių automobilių, naudojančiu iškastinị kurą. Siekdamos paskatinti elektra varomo transporto priemonių plètrą, vyriausybès igyvendina skatinimo politikos instrumentus, kurie didina šiuc priemonių konkurencingumą ir populiarumą vartotojų preferencijose [6]. Elektromobilių naudojimo paskatos ir jų efektyvumas tapo aktualiu mokslinių tyrimų objektu. Šio straipsnio tyrimo problema - nepaisant taikomų įvairių elektromobilių naudojimo skatinimo vertinimo būdų, vis dar trūksta priemonių efektyvumo vertinimo sistemos, kuri visapusiškai apibendrintų vartotojų preferencijas, igyvendinamumą, veiksmingumą. Šio tyrimo tikslas - išanalizuoti elektromobilių naudojimo skatinimo priemonių vertinimo praktiką ir konceptualizuoti skatinimo priemonių efektyvumo vertinimo modeli. Tyrimui naudoti metodai: mokslinès literatūros analizé, sisteminimas ir palyginamoji analizè.

\section{ELEKTROMOBILIŲ PANAUDOJIMO SKATINIMO TEORINĖS PRIELAIDOS}

Nèra vieno būdo, kaip paskatinti elektromobilių plètrą. Skirtingos šalys ir miestai turi skirtingas sistemas, igyvendinimo patirtis ir skatinimo priemones. Skiriasi ir igyvendinimo lygmuo: vienos priemonès igyvendinamos nacionaliniu lygiu, kitos labiau orientuotos ị lokalius resursus ir savivaldos veiklos sferas [6]. Analizuodami skirtingų šalių patirtis ir mokslinę literatūrą, P. Mačiulis ir kt. nustatė penkiolika elektra varomų transporto priemonių skatinimo politikos krypčių, išskyrè penkiolika nacionalinio ir dvylika savivaldybės lygmens konkrečių skatinimo priemonių, kurios buvo taikytos skirtingose valstybèse ar miestuose [7]. Daugeliu atvejų nacionalinès ir lokalios valdžios igyven- dinamos priemonès skiriasi dèl netapačių politikos krypčiu, kurias lemia skatinimo sistemos mastas [8]. Veiksmų spektras priklauso ir nuo kiekvienos vietovès fizinio ir politinio konteksto. Pavyzdžiui, nelygus Norvegijos reljefas suteikia galimybę apmokestinti tunelius ir atleisti elektromobilius nuo šių mokesčių; Šanchajaus (Kinija) transporto priemonių kvotų sistema leidžia suteikti lengvatinę registraciją elektromobiliams [9].

Investavimas i naujas technologijas yra susijęs su nepatirtais privalumais, todèl išbandyta ir aiškiai suprantama inovacija reiškia mažesnị neužtikrintumą potencialiems vartotojams [10]. Galima teigti, kad elektromobilių rinką lemia potencialių vartotojų supratimas apie jų naudą, privalumų ir naudojimo aspektų išmanymas. Kitaip tariant, didejant supratimui ir patirčiai, kartu auga ir produkto vartojimas. Tai patvirtina ir $\mathrm{N}$. Wango su kolegomis vykdytas tyrimas, kuris atskleidè, kad vartotojų suvokimas apie elektromobilius gali būti reikšminga kliūtis šių transporto priemonių rinkos plètrai [11]. Egzistuoja ìvairaus pobūdžio priemonès ir iniciatyvos, kuriomis siekiama įveikti minètą barjerą.

Rinkos, kurios gali pasigirti plačiu elektromobiliu paplitimu ir aktyviu augimu, naudoja kur kas sudetingesnes ir visapusiškas skatinimo sistemas [12]. Reikia pripažinti, kad netaršių automobilių pardavimams itakos gali turèti ne tik aktyvios tiesioginès valdžios igyvendinamos skatinimo priemonès, bet ir daug kitu veiksnių, pavyzdžiui, kuro kainos, automobilių modelių kainos, gyventojų pajamos [13]. Daliai šių rodiklių valdžia taip pat gali daryti įtaką, o tai lemia ir elektromobiliu paklausą. Dar vienas svarbus veiksnys - vartotojų lūkesčiai. Todèl tiriant elektromobilių naudojimo skatinimo priemones dažnai atsižvelgiama $\mathfrak{i}$ potencialius elektromobilių pirkèjus, tiriamos vartotojų preferencijos [14].

Galima rasti nemažai mokslinès literatūros ir studijų, kuriose analizuojant elektromobilių rinkas siekiama ịvertinti finansinių skatinimo priemonių veiksmingumą. Šiuose tyrimuose ieškoma ryšių tarp elektromobilių pardavimo dinamikos ir duomenų, rodančių pirkimo paskatų mastą, jų vertę ir ịtaką. Daugelyje tyrimų naudojami agreguoti pardavimų duomenys [4]. Visuminès paklausos analizè tinkamiausia siekiant identifikuoti ilgalaikes automobilių pirkimo 
tendencijas didelèse teritorijose. Prognozuojama skirtingų transporto priemonių technologijų pardavimų rinkos dalis. Dažnai šios prognozės numato skirtingų transporto priemonių pardavimo potencialą iki 2020, 2030 ar 2050 metų. Šiuo atveju elektromobilių pirkejjų specifinès savybès ir preferencijos nèra nustatomos. Prie visuminès paklausos analizès galima priskirti difuzijos modelius (ang. diffusion models) ir atsipirkimo analizę (angl. payback analysis), jas ir aptarsime šiame straipsnyje.

Rečiau sutinkami neagreguoti duomenys, kaip, pavyzdžiui, A. C. Mersky’o ir kt. studijoje, kurioje $\mathfrak{i}$ duomenų rinkinius ittraukti atskiri kiekvieno parduoto elektromobilio duomenys [15]. Tai apima pardavimo vietą, transporto priemones markę ir modelį, taip pat informaciją apie pirkejją. Dauguma studijų tiria metinius duomenis, tačiau galima rasti ir tokių, kurios orientuojasi i ketvirčio ar ménesio tendencijas [4]. Nevisuminès paklausos prognozès yra dažniau sutinkamas kito pobūdžio tyrimuose, kai nustatomos elektromobilių pirkèjų charakteristikos ir jų lokalizacija. Agreguotoji (bendroji) analizė atsižvelgia $\mathfrak{i}$ atskirų asmenų (ar namų ūkių) savybes, ju potencialias preferencijas ir pirkimo motyvaciją. Apibendrintai galima teigti, kad agreguotąją analizę sudaro pasirinkimo modeliai (angl. choice models), apribojimų analizè (angl. constraints analysis) ir vartotojų pasirinkimų simuliacijos [16].

1 lentelè. Skirtingi požiūriai j elektromobilių rinkos analizę [1]

\begin{tabular}{c|c}
\hline $\begin{array}{c}\text { Agreguotoji } \\
\text { (bendroji) } \\
\text { analizè }\end{array}$ & Difuzijos modeliai \\
\cline { 2 - 2 } & Atsipirkimo analizè \\
\hline \multirow{2}{*}{$\begin{array}{c}\text { Neagreguotoji } \\
\text { analizè }\end{array}$} & Pasirinkimo modeliai \\
\cline { 2 - 2 } & Apribojimu analizè \\
\cline { 2 - 2 } & $\begin{array}{c}\text { Vartotojų pasirinkimų } \\
\text { simuliacijos }\end{array}$ \\
\hline
\end{tabular}

Kitas būdas, tinkamas klasifikuoti elektromobilių skatinimo priemonių vertinimo metodikas, yra jų skirstymas pagal tyrimo specifiką. Šio straipsnio autoriai pasirinko tris apibendrintas grupes ir jas aptare detaliau: statistine analize paremti tyrimai, apklausomis paremti tyrimai ir kiti skatinimo priemonių tyrimo būdai.

\section{ELEKTROMOBILIŲ PANAUDOJIMO SKATINIMO PRIEMONIŲ TYRIMŲ PALYGINAMASIS VERTINIMAS}

Statistine analize paremti tyrimai. W. Sierzchula ir kt. pirmieji regresiniais metodais analizavo vyriausybès skatinimo politikos poveiki empiriniams elektromobilių rinkos duomenims. Jie pasirinko $2012 \mathrm{~m}$. 30-ties šalių duomenis, analizavo naudodami regresinę analizę ir taikydami mažiausiųjų kvadratų metodą. Tyrime nustatytas stiprus ryšys tarp elektromobilių pardavimų ir finansinių skatinimo priemonių, vietinès elektromobilių gamybos ir ịkrovimo stotelių, tenkančiu vienam gyventojui. Tyrëjai pabrèžè, kad šiu veiksnių gali nepakakti numatant rinkos plètrą, nes gali būti nepastebima dinamika didinant elektromobilių pardavimus [17]. Regresinę analizę savo tyrimuose naudojo ir S. Li su kolegomis bei D. Diamondas, tačiau pastarasis vertino hibridines transporto priemones [18]. Kitas plačiai paplitęs metodas, taikomas renkantis reikšmingus rodiklius statistiniams modeliams kurti, - tai pažingsninè tiesinè regresija (angl. stepwise linear regression) [19]. A. C. Mersky’as ir kt. pritaike šį metodą noredami ištirti regioninius skirtumus, susijusius su elektromobilių paplitimu Norvegijoje. Analizei jie panaudojo neagreguotus pardavimų duomenis Norvegijos savivaldybèse nuo 2000 iki 2013 metų. Tyrejjai nustatè, kad ịkrovimo infrastruktūra yra svarbiausias elektra varomų automobilių pardavimo prognozavimo elementas. I šią analizę nebuvo įtrauktos finansinès paskatos, kurios buvo siūlomos nacionaliniu lygmeniu ir buvo vienodos visose Norvegijos savivaldybès [15]. Pažingsninę tiesinę regresiją naudojo ir N. Wangas su kolegomis. Jie naudodami 41 pilotinio projekto skirtinguose miestuose duomenis (2013-2014 m. duomenys) tyrè skatinimo sistemos ittaką elektromobilių pardavimui Kinijoje [11].

Hedoninè regresija yra nustatytų preferencijų metodas (angl. revealed preference method), kuriuo galima ịvertinti prekès paklausą arba lygiavertę jos vertę vartotojams. Naudojant šį metodą tiriamasis daiktas suskaidomas $\mathfrak{i}$ jo sudedamąsias dalis ir nustatomos kiekvienos charakteristikos rinkos vertė [20]. Šiuo metodu tirdami elektromobilių ir hibridinių elektromobilių rinką naudojosi D. Diamondas, A. Chandra ir kt., K. S. Gallagheris ir E. Muehleggeris, A. Jennas 
ir kt., S. Shewmake'as ir L. Jarvis, S. Vergis ir B. Chenas. Pastarieji tyrè finansinių skatinimo priemonių poveikį elektromobilių rinkos dalies pokyčiams JAV, remdamiesi $2013 \mathrm{~m}$. duomenimis. Be to, nustatyta, kad nepaisant vartotojų, geografijos ir energijos rinkos savybiu, ikkrovimo stotelių prieinamumas daro didžiausią ittaką akumuliatoriniams elektromobiliams, o ikraunamiems hibridiniams elektromobiliams finansinès skatinimo priemonès turi didesnị poveikị [21].

Kitas metodas, kuriuo naudojantis buvo vertinamos elektromobilių skatinimo priemonès, yra susijęs su paneliniais duomenimis (angl. panel data). Tai yra duomenys, gauti kelis laiko momentus stebint tuos pačius subjektus arba sekant tos pačios subjektų grupés evoliuciją. $\mathrm{Pa}$ neliniai duomenys turi dvi dimensijas - vienalaikių duomenų ir laikinių sekų [22]. Būtent panelinių duomenų regresiją naudojo C. Münzelis ir kt., kurie analizavo elektromobilių pardavimų duomenis 32 Europos šalyse nuo 2010 iki 2017 metų. Atliko ekonominius tyrimus, susijusius su pirkimo skatinimo priemoniu poveikiu, bei analizavo kitus veiksnius, tokius kaip pajamų ir degalų kainų pokyčiai. Tyrimo autoriams pasirode svarbu įvesti tendencijos kintamąji, kuris leidžia pastebèti bendrus naujos technologijos sklaidos pokyčius [9]. Šia metodika taip pat naudojosi Y. Q. Qiua ir kt., kurie iš Kinijos pilotinių miestų duomenų tyrė elektromobilių ịvairių skatinamųjų politikos krypčių efektyvumą municipaliteto lygmeniu. Regresijos rezultatai rodo teigiamą ryši tarp elektromobilių pardavimo masto ir dviejų paklausos politikos krypčių: įkrovimo paslaugos kainos nuolaidos ir infrastruktūros irengimo subsidijos [23]. Panelinių duomenų regresiją naudodami fiksuotų efektų modeli (angl. fixed effect model) atliko D. Diamondas, A. Chandra ir kt., K. S. Gallagheris, E. Muehleggeris, A. Jennas ir kt. Šiame modelyje parametrai yra fiksuoti arba neatsitiktiniai dydžiai. Priešingai nei atsitiktinių efektų modeliui (angl. random effects models) ir mišriam modeliui, kuriu parametrai laikomi atsitiktiniais kintamaisiais.

2 lentelè. Statistine analize paremti elektromobilių naudojimo skatinimo priemonių efektyvumo tyrimai (sudaryta straipsnio autorių)

\begin{tabular}{|c|c|c|c|c|c|}
\hline \multicolumn{2}{|c|}{ Autorius } & Metodai & Regionas & Automobilio rūšis & $\begin{array}{l}\text { Nagrinèti } \\
\text { skatinimo } \\
\text { priemonių } \\
\text { tipai }\end{array}$ \\
\hline $\begin{array}{l}\text { Javid ir } \\
\text { Nejat }\end{array}$ & {$[24]$} & $\begin{array}{l}\text { Daugialypè logistinè } \\
\text { regresija / Polinominis logit } \\
\text { modelis }\end{array}$ & $\begin{array}{l}\text { Kalifornija, } \\
\text { JAV }\end{array}$ & Elektromobiliai & $\begin{array}{l}\text { Finansinès ir } \\
\text { nefinansinès }\end{array}$ \\
\hline $\begin{array}{l}\text { Sierzchula } \\
\quad \text { ir kt. }\end{array}$ & [17] & $\begin{array}{l}\text { Daugialypè tiesinè } \\
\text { regresija / Hedoninè } \\
\text { regresija / Sujungtų } \\
\text { mažiausiujų kvadratų metodu } \\
\text { paremta regresija }\end{array}$ & $\begin{array}{l}\text { lvairios } \\
\text { šalys }\end{array}$ & $\begin{array}{l}\text { Elektromobiliai su } \\
\text { akumuliatoriais, iš išorès } \\
\text { ¡kraunami hibridiniai } \\
\text { elektromobiliai }\end{array}$ & $\begin{array}{l}\text { Finansinès ir } \\
\text { nefinansinès }\end{array}$ \\
\hline Wang ir kt. & [11] & $\begin{array}{l}\text { Daugialypè tiesinė } \\
\text { regresija / Pažingsninè tiesinè } \\
\text { regresija }\end{array}$ & Kinija & $\begin{array}{l}\text { Iš išorès įkraunami } \\
\text { elektromobiliai ir } \\
\text { hibridiniai elektromobiliai, } \\
\text { elektromobiliai su } \\
\text { akumuliatoriais, }\end{array}$ & $\begin{array}{l}\text { Finansinès ir } \\
\text { nefinansinès }\end{array}$ \\
\hline Ma ir kt. & {$[25]$} & $\begin{array}{c}\text { Daugiamatis kointegracijos } \\
\text { modelis / Paklaidų korekcijos } \\
\text { modelis }\end{array}$ & Kinija & Elektromobiliai & $\begin{array}{l}\text { Finansinès ir } \\
\text { nefinansinès }\end{array}$ \\
\hline Wee ir kt. & {$[26]$} & $\begin{array}{l}\text { Daugiapakopè regresija su } \\
\text { fiksuotais efektais }\end{array}$ & JAV & $\begin{array}{l}\text { Iš išorès įkraunami } \\
\text { elektromobiliai ir } \\
\text { hibridiniai elektromobiliai, } \\
\text { elektromobiliai su } \\
\text { akumuliatoriais }\end{array}$ & $\begin{array}{l}\text { Finansinès ir } \\
\text { nefinansinès }\end{array}$ \\
\hline
\end{tabular}


2 lentelè. (Tęsinys)

\begin{tabular}{|c|c|c|c|c|c|}
\hline Autorius & & Metodai & Regionas & Automobilio rūšis & $\begin{array}{l}\text { Nagrinèti } \\
\text { skatinimo } \\
\text { priemonių } \\
\text { tipai }\end{array}$ \\
\hline $\begin{array}{l}\text { Shewmake } \\
\text { ir Jarvis }\end{array}$ & {$[20]$} & Hedoninè regresija & JAV & $\begin{array}{c}\text { Hibridiniai } \\
\text { elektromobiliai }\end{array}$ & $\begin{array}{l}\text { Didelio } \\
\text { užimtumo } \\
\text { transporto } \\
\text { priemonių } \\
\text { juosta }\end{array}$ \\
\hline $\begin{array}{l}\text { Vergis ir } \\
\text { Chen }\end{array}$ & {$[21]$} & Hedoninè regresija & JAV & $\begin{array}{c}\text { Elektromobiliai su } \\
\text { akumuliatoriais, iš išorès } \\
\text { ¿kraunami hibridiniai } \\
\text { elektromobiliai }\end{array}$ & $\begin{array}{l}\text { Mokesčiu } \\
\text { lengvatos }\end{array}$ \\
\hline Mersky ir kt. & {$[15]$} & $\begin{array}{l}\text { Hedoninè } \\
\text { regresija / Pažingsninè tiesinè } \\
\text { regresija }\end{array}$ & Norvegija & $\begin{array}{c}\text { Elektromobiliai } \\
\text { su akumuliatoriais }\end{array}$ & $\begin{array}{l}\text { Automobilių } \\
\text { mokesčiu } \\
\text { registravimo } \\
\text { išimtys ir } \\
\text { pridètinès } \\
\text { vertès } \\
\text { mokesčio } \\
\text { lengvatos }\end{array}$ \\
\hline $\begin{array}{l}\text { Chandra } \\
\text { ir kt. }\end{array}$ & {$[27]$} & $\begin{array}{c}\text { Hedoninè regresija / Panelinių } \\
\text { duomenų regresija su } \\
\text { fiksuotais efektais }\end{array}$ & Kanada & Hibridiniai elektromobiliai & $\begin{array}{l}\text { Mokesčiu } \\
\text { lengvatos }\end{array}$ \\
\hline Jenn ir kt. & {$[28]$} & $\begin{array}{l}\text { Hedoninè regresija / Panelinių } \\
\text { duomenų regresija su } \\
\text { fiksuotais efektais / Modelis } \\
\text { su fiktyviais kintamaisiais } \\
\text { naudojant momentų metodą }\end{array}$ & JAV & Hibridiniai elektromobiliai & $\begin{array}{l}\text { Mokesčių } \\
\text { kreditai }\end{array}$ \\
\hline $\begin{array}{l}\text { Gallagher ir } \\
\text { Muehlegger }\end{array}$ & {$[29]$} & $\begin{array}{l}\text { Hedoninè regresija / Panelinių } \\
\text { duomenų regresija su } \\
\text { fiksuotais efektais }\end{array}$ & JAV & Hibridiniai elektromobiliai & $\begin{array}{l}\text { Mokesčiu } \\
\text { kreditai ir } \\
\text { lengvatos }\end{array}$ \\
\hline Diamond & {$[18]$} & $\begin{array}{l}\text { Hedoninè regresija / Sujungtu } \\
\text { mažiausių kvadratų metodu } \\
\text { paremta regresija / Panelinių } \\
\text { duomenų regresija su } \\
\text { fiksuotais efektais }\end{array}$ & JAV & Hibridiniai elektromobiliai & $\begin{array}{l}\text { Mokesčiu } \\
\text { kreditai ir } \\
\text { lengvatos }\end{array}$ \\
\hline Qiua ir kt. & {$[23]$} & Panelinių duomenų regresija & Kinija & Elektromobiliai & $\begin{array}{l}\text { Finansinès ir } \\
\text { nefinansinès }\end{array}$ \\
\hline $\begin{array}{l}\text { Münzel } \\
\text { ir kt. }\end{array}$ & {$[19]$} & Panelinių duomenų regresija & $\begin{array}{l}\text { Europos } \\
\text { valstybės }\end{array}$ & Elektromobiliai & $\begin{array}{l}\text { Pirkimo } \\
\text { paskatos }\end{array}$ \\
\hline Li ir kt. & {$[30]$} & $\begin{array}{c}\text { Regresijos modeliai, } \\
\text { naudojantys mažiausiujų } \\
\text { kvadratų metodą ar momentų } \\
\text { metodą }\end{array}$ & JAV & $\begin{array}{l}\text { Iš išorès įkraunami } \\
\text { elektromobiliai }\end{array}$ & $\begin{array}{l}\text { Finansinès ir } \\
\text { nefinansinès }\end{array}$ \\
\hline Jenn ir kt. & {$[31]$} & $\begin{array}{l}\text { Regresijos modeliai, } \\
\text { naudojantys momentų } \\
\text { metodą }\end{array}$ & JAV & $\begin{array}{l}\text { Iš išorès įkraunami } \\
\text { elektromobiliai }\end{array}$ & $\begin{array}{l}\text { Finansinès ir } \\
\text { nefinansinès }\end{array}$ \\
\hline
\end{tabular}

A. Jennas ir kt. išanalizavo 2010-2015 m. ménesinius JAV nacionalinio lygmens duomenis, taikydami fiksuoto efekto modeli (angl. fixed effects model) ir atsižvelgdami ị laiko, regioninius 
ir transporto priemonių modelių veiksnius. Savo regresijai įvertinti jie naudojo momentų metodą (angl. generalized method of moments) [31]. Šiame tyrime įtrauke kintamojo vèlavimą, siekdami atsižvelgti $\mathfrak{i}$ galimą endogeniškumą modelyje, kuris gali būti susijęs su didesne vyriausybių motyvacija skatinti elektromobilius tose šalyse, kur jų poreikis jau yra didesnis [19]. Momentų metodą savo tyrimuose naudojo ir J. Li su kolegomis [30].

Apklausomis paremti tyrimai. Šioje grupeje mokslinejje literatūroje dažniausiai sutinkami pasirengimo mokèti tyrimai. Pagrindiniai būdai ivertinti vartotojų pasirengimą moketi yra naudoti nustatytų ir pareikštų preferencijų metodai. Nustatytų preferencijų metodais siekiama pasinaudoti taikant kelionès išlaidų ir hedonistinių kainų metodus [32], taip pat aukcionus, lauko bei laboratorinius eksperimentus [33]. Skirtingai nei pareikštų preferencijų metodas, nustatytų preferencijų metodas nèra dažnai sutinkamas elektromobilių skatinimo politikos analizèse. Pareikštų preferencijų metodai plačiai naudojami rinkodaroje ir taikomi sprendžiant vartotojų pasirinkimo bei rinkos prognozavimo problemas, kai duomenų apie vartotojų preferencijas nèra arba jie sunkiai gaunami [34].

Taikant pareikštų preferencijų metodus galima nustatyti subjektų pasirengimą mokèti dviem būdais: pirma, naudojant tiesiogines ap- klausas, kai respondentai tiesiogiai atsako, kiek jie sutiktų mokèti už tam tikras gèrybes; antra, netiesiogines apklausas, kurios paremtos sudètingesniais pasirengimo mokèti nustatymo metodais [32]. Pagrindiniai iš jų yra diskretaus pasirinkimo modelis ir jungtinè analizè [33]. Jungtinè analizè (angl. conjoint analysis) yra senas ir plačiai naudojamas metodas, kuris leidžia nustatyti vartotojų preferencijų struktūrą netiesioginiu būdu [35]. Tyrime dalyvaujantys respondentai, remdamiesi kriterijais, ịvertina arba nustato neivardytas skirtingas skatinimo politikos alternatyvas. Antrame etape tyrimo dalyviu pagal atskirus kriterijus pareikštos preferencijos yra išskaidomos taikant regresinę analizę ir nustatomos netiesiogiai respondentų pasirinktos skatinimo politikos priemonès [32]. Jungtinès analizės metodą savo darbe pritaikè J. P. Helvestonas ir kt., taip pat T. Lievenas.

Diskretaus pasirinkimo modeliai aprašo, paaiškina ir prognozuoja pasirinkimą iš dvieju ar daugiau diskrečių alternatyvų, pavyzdžiui, pasirenkant transporto priemonès rūšì. Kitaip tariant, šie modeliai naudojami situacijose, kai galimas rezultatas yra diskretus dydis. Šiems uždaviniams spręsti naudojamos tokios technikos kaip logistinè regresija ir probit regresija. Šie modeliai ịvertina tikimybę, kuria remdamasis žmogus pasirenka tam tikrą alternatyvą. Modeliai dažnai naudojami prognozuojant, kaip pasikeis

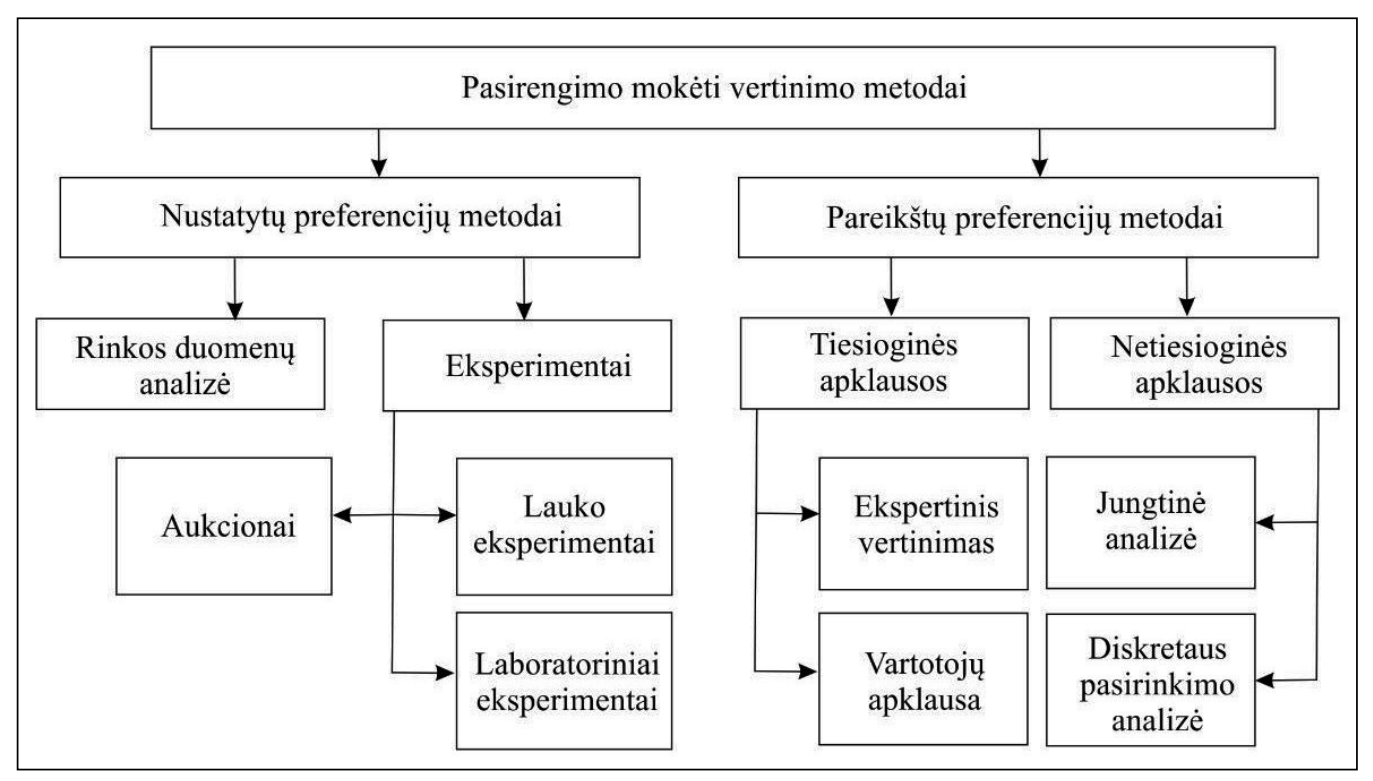

1 pav. Pasirengimo mokèti vertinimo metodų klasifikavimas [33] 
žmogaus pasirinkimas pakitus alternatyvų atributams. Pasirinkimų rinkinys, kurị sudaro galimos alternatyvos, turi tenkinti tris pagrindinius reikalavimus [36]:

1. Alternatyvų rinkinys turi būti išsamus, ir žmogus privalo pasirinkti alternatyvą iš rinkinio.

2. Žmogus gali pasirinkti tik vieną alternatyvą iš rinkinio, tai reiškia, kad, pasirinkęs vieną alternatyvą, jis atsisako kitų.

3. Rinkinyje turi būti baigtinis skaičius alternatyvų.

Vartotojų preferencijų tyrimuose analizuojant elektromobilius dažniausiai sutinkami finansiniai, techniniai, infrastruktūros ir skatinimo politikos atributai [37]. Neįmanoma žinoti visų veiksnių, kurie lemia žmogaus pasirinkimą, todèl diskretaus pasirinkimo modeliai yra grịsti stochastinèmis prielaidomis ir specifikacijomis, siekiant ịvertinti nestebimas priežastis [36]. Šio straipsnio autoriai nustate, kad diskretaus pasirinkimo modeliai yra dažniausiai sutinkami mokslinejje literatūroje, kuri analizuoja skatinimo priemonių efektyvumą. S. Ma ir kt., naudodami šį modeli, tyre Kinijos vartotojų pasirengimo mokèti pokyčius pagal taikomas elektromobilių skatinimo priemones. Atsitiktiniu būdu pasirinkti 1719 respondentai užpilde anketas. Pasirengimas mokèti nustatytas taikant polinominị logit ir mišrų logit modelius. Taip pat buvo tiriamas ryšys tarp respondento heterogeniškumo ir skatinimo priemonių pasirinkimo [38]. Diskretaus pasirinkimo modelius naudojo G. Ewingas ir E. Sarigollu'as, L. Qianas ir D. Soopramanienas, A. Hackbarthas ir R. Madleneris, V. Lee ir kt.

3 lentelè. Apklausomis paremti elektromobilių naudojimo skatinimo priemonių efektyvumo tyrimai (sudaryta straipsnio autorių)

\begin{tabular}{|c|c|c|c|c|c|}
\hline Autorius & & Metodai & Regionas & Automobilio rūšis & $\begin{array}{l}\text { Nagrinèti skatinimo } \\
\text { priemonių tipai }\end{array}$ \\
\hline Krupa ir kt. & [39] & Anketinè apklausa & JAV & $\begin{array}{l}\text { Iš išorès įkraunami } \\
\text { hibridiniai elektromobiliai }\end{array}$ & $\begin{array}{l}\text { Finansinès ir } \\
\text { nefinansinès } \\
\text { priemonès }\end{array}$ \\
\hline Wang ir kt. & {$[12]$} & Anketinė apklausa & Kinija & Elektromobiliai & $\begin{array}{l}\text { Finansinès ir } \\
\text { nefinansinès } \\
\text { priemonès }\end{array}$ \\
\hline Larson ir kt. & [40] & $\begin{array}{c}\text { Anketinè } \\
\text { apklausa / Pasirinkimo } \\
\text { eksperimentas }\end{array}$ & Kanada & $\begin{array}{l}\text { Elektromobiliai su } \\
\text { akumuliatoriais }\end{array}$ & \\
\hline Krause ir kt. & [41] & $\begin{array}{c}\text { Anketinè } \\
\text { apklausa / Žinių ir } \\
\text { sąmoningumo tyrimas }\end{array}$ & JAV & $\begin{array}{c}\text { Elektromobiliai su } \\
\text { akumuliatoriais, iš išorès } \\
\text { ¡̨kraunami hibridiniai } \\
\text { elektromobiliai }\end{array}$ & $\begin{array}{l}\text { Mokesčių kreditas ir } \\
\text { lengvatos }\end{array}$ \\
\hline Hardman ir Tal & {$[42]$} & $\begin{array}{c}\text { Apklausa po } \\
\text { pirkimo / Anketinè } \\
\text { Apklausa }\end{array}$ & $\begin{array}{l}\text { Kalifornija, } \\
\text { JAV }\end{array}$ & $\begin{array}{l}\text { Elektromobiliai su } \\
\text { akumuliatoriais }\end{array}$ & $\begin{array}{c}\text { Mokesčių kreditas ir } \\
\text { lengvatos }\end{array}$ \\
\hline Bjerkan ir kt. & [43] & $\begin{array}{c}\text { Apklausa po } \\
\text { pirkimo / Anketinè } \\
\text { Apklausa }\end{array}$ & Norvegija & $\begin{array}{l}\text { Elektromobiliai su } \\
\text { akumuliatoriais }\end{array}$ & $\begin{array}{l}\text { Automobilio } \\
\text { registravimo } \\
\text { mokesčio išimtys } \\
\text { ir pridètinès vertès } \\
\text { mokesčio lengvata }\end{array}$ \\
\hline Tal ir Nicholas & [44] & $\begin{array}{c}\text { Apklausa po } \\
\text { pirkimo / Anketinè } \\
\text { apklausa / Polinominis } \\
\text { logit modelis }\end{array}$ & JAV & $\begin{array}{c}\text { Elektromobiliai su } \\
\text { akumuliatoriais, iš išorès } \\
\text { ikraunami hibridiniai } \\
\text { elektromobiliai }\end{array}$ & Mokesčių kreditas \\
\hline $\begin{array}{l}\text { Sánchez-Braza } \\
\text { ir kt. }\end{array}$ & {$[45]$} & $\begin{array}{c}\text { Binarinis pasirinkimo } \\
\text { modelis / Probit } \\
\text { modelis }\end{array}$ & Ispanija & Elektromobiliai & $\begin{array}{l}\text { Automobilių } \\
\text { mokesčių išimtys }\end{array}$ \\
\hline
\end{tabular}


3 lentelè. (Tęsinys)

\begin{tabular}{|c|c|c|c|c|c|}
\hline Autorius & & Metodai & Regionas & Automobilio rūšis & $\begin{array}{c}\text { Nagrinèti skatinimo } \\
\text { priemonių tipai }\end{array}$ \\
\hline $\begin{array}{c}\text { Qian ir } \\
\text { Soopramanien }\end{array}$ & [46] & $\begin{array}{l}\text { Diskretaus pasirinkimo } \\
\text { modelis }\end{array}$ & Kinija & $\begin{array}{l}\text { Alternatyvaus kuro } \\
\text { transporto priemonės }\end{array}$ & $\begin{array}{l}\text { Finansinès ir } \\
\text { nefinansinès } \\
\text { priemonès }\end{array}$ \\
\hline $\begin{array}{l}\text { Hackbarth ir } \\
\text { Madlener }\end{array}$ & [47] & $\begin{array}{c}\text { Diskretaus pasirinkimo } \\
\text { modelis }\end{array}$ & Vokietija & Elektromobiliai & $\begin{array}{l}\text { Finansinès ir } \\
\text { nefinansinès } \\
\text { priemonès }\end{array}$ \\
\hline $\begin{array}{l}\text { Ewing ir } \\
\text { Sarigollu }\end{array}$ & [48] & $\begin{array}{l}\text { Diskretaus pasirinkimo } \\
\text { modelis / Polinominis } \\
\text { logit modelis }\end{array}$ & JAV & Elektromobiliai & $\begin{array}{l}\text { Finansinès } \\
\text { priemonès }\end{array}$ \\
\hline Ma ir kt. & [38] & $\begin{array}{l}\text { Diskretaus pasirinkimo } \\
\text { modelis / Polinominis } \\
\text { logit modelis / Mišrus } \\
\text { logit modelis }\end{array}$ & Kinija & Elektromobiliai & $\begin{array}{l}\text { Finansinès ir } \\
\text { nefinansinès } \\
\text { priemonès }\end{array}$ \\
\hline Lee ir kt. & [49] & $\begin{array}{l}\text { Diskretaus pasirinkimo } \\
\text { modelis / Sistemos } \\
\text { dinamikos modelis }\end{array}$ & Korèja & Hibridiniai elektromobiliai & $\begin{array}{l}\text { Finansinès } \\
\text { priemonès }\end{array}$ \\
\hline $\begin{array}{l}\text { Helveston } \\
\text { ir kt. }\end{array}$ & {$[50]$} & Jungtinè analizè & $\begin{array}{l}\text { JAV ir } \\
\text { Kinija }\end{array}$ & $\begin{array}{l}\text { Elektromobiliai su } \\
\text { akumuliatoriais, iš išorès } \\
\text { ikraunami hibridiniai } \\
\text { elektromobiliai }\end{array}$ & Subsidijos \\
\hline Lieven & {$[51]$} & $\begin{array}{c}\text { Jungtinè } \\
\text { analizè / Hierarchinis } \\
\text { Bajeso metodas/ Kano } \\
\text { metodas }\end{array}$ & $\begin{array}{l}\text { Skirtingos } \\
\text { šalys }\end{array}$ & Elektromobiliai & $\begin{array}{l}\text { Finansinès ir } \\
\text { nefinansinès } \\
\text { priemonès }\end{array}$ \\
\hline $\begin{array}{l}\text { Skerlos ir } \\
\text { Winebrake }\end{array}$ & {$[52]$} & Kokybinè diskusija & JAV & $\begin{array}{c}\text { Iš išorès įkraunami } \\
\text { hibridiniai elektromobiliai }\end{array}$ & Mokesčių kreditas \\
\hline Zhang ir kt. & {$[53]$} & Kokybinè diskusija & JAV & Elektromobiliai & $\begin{array}{l}\text { Finansinès ir } \\
\text { nefinansinès } \\
\text { priemonès }\end{array}$ \\
\hline $\begin{array}{l}\text { Aasness ir } \\
\text { Aarestrup }\end{array}$ & {$[54]$} & Kokybinè diskusija & $\begin{array}{l}\text { Oslas, } \\
\text { Norvegija }\end{array}$ & Elektromobiliai & $\begin{array}{l}\text { Finansinès ir } \\
\text { nefinansinès } \\
\text { priemonès }\end{array}$ \\
\hline $\begin{array}{l}\text { Holtsmark ir } \\
\text { Skonhoft }\end{array}$ & {$[55]$} & Kokybinè diskusija & Norvegija & Elektromobiliai & $\begin{array}{l}\text { Finansinès ir } \\
\text { nefinansinès } \\
\text { priemonès }\end{array}$ \\
\hline $\begin{array}{l}\text { Ajanovic ir } \\
\text { Haas }\end{array}$ & {$[56]$} & Kokybinè diskusija & $\begin{array}{l}\text { Skirtingi } \\
\text { miestai }\end{array}$ & Elektromobiliai & $\begin{array}{l}\text { Finansinès ir } \\
\text { nefinansinès } \\
\text { priemonès }\end{array}$ \\
\hline Bakker ir Trip & {$[57]$} & Kokybinè diskusija & - & Elektromobiliai & $\begin{array}{l}\text { Finansinès ir } \\
\text { nefinansinès } \\
\text { priemonès }\end{array}$ \\
\hline Kester ir kt. & {$[58]$} & $\begin{array}{c}\text { Kokybinè } \\
\text { diskusija / kokybinè } \\
\text { palyginamoji analizė }\end{array}$ & $\begin{array}{l}\text { Šiaurès } \\
\text { regiono } \\
\text { šalys }\end{array}$ & Elektromobiliai & $\begin{array}{l}\text { Finansinès ir } \\
\text { nefinansinès } \\
\text { priemonès }\end{array}$ \\
\hline Sheldon ir Dua & [59] & $\begin{array}{c}\text { Kontrafaktinis } \\
\text { modeliavimas / Mišrus } \\
\text { logit modelis }\end{array}$ & JAV & $\begin{array}{l}\text { Iš išorès įkraunami } \\
\text { elektromobiliai }\end{array}$ & Subsidijos \\
\hline
\end{tabular}




\begin{tabular}{|c|c|c|c|c|c|}
\hline Autorius & & Metodai & Regionas & Automobilio rūšis & $\begin{array}{c}\text { Nagrinèti skatinimo } \\
\text { priemonių tipai }\end{array}$ \\
\hline $\begin{array}{l}\text { Dumortier } \\
\text { ir kt. }\end{array}$ & {$[60]$} & $\begin{array}{c}\text { Nuosavybès } \\
\text { bendru kaštų } \\
\text { analizė / Anketinè } \\
\text { apklausa }\end{array}$ & JAV & Elektromobiliai & $\begin{array}{l}\text { Finansinès } \\
\text { priemonès }\end{array}$ \\
\hline $\begin{array}{l}\text { Langbroek } \\
\text { ir kt. }\end{array}$ & {$[61]$} & $\begin{array}{c}\text { Nurodyto pasirinkimo } \\
\text { eksperimentas / } \\
\text { Anketinè apklausa }\end{array}$ & Švedija & $\begin{array}{l}\text { Elektromobiliai su } \\
\text { akumuliatoriais }\end{array}$ & $\begin{array}{l}\text { Finansinès ir } \\
\text { nefinansinès } \\
\text { priemonès }\end{array}$ \\
\hline $\begin{array}{l}\text { Potoglou ir } \\
\text { Kanaroglou }\end{array}$ & {$[62]$} & $\begin{array}{c}\text { Nurodyto pasirinkimo } \\
\text { eksperimentas / } \\
\text { Eksperimentinis } \\
\text { dizainas }\end{array}$ & Kanada & $\begin{array}{l}\text { Hibridiniai, alternatyvaus } \\
\text { kuro automobiliai }\end{array}$ & $\begin{array}{l}\text { Finansinès } \\
\text { priemonès }\end{array}$ \\
\hline Qian ir kt. & {$[63]$} & $\begin{array}{l}\text { Nurodyto pasirinkimo } \\
\text { eksperimentas / Mišrus } \\
\text { logit modelis }\end{array}$ & Kinija & Elektromobiliai & $\begin{array}{l}\text { Finansinès ir } \\
\text { nefinansinès } \\
\text { priemonès }\end{array}$ \\
\hline
\end{tabular}

J. Dumortieras ir kt., naudodami nuosavybès kaštų analizės metodą ir apklausdami internetu, ištyrè vartotojams tenkančius pirkimo, kuro ir automobilio išlaikymo kaštus bei ịvertino elektromobilių skatinimo priemonių poveiki bendriesiems kaštams [60]. Vienas iš būdų vertinti skatinimo priemonių poveiki yra tyrimas po pirkimo (angl. post purchase surveys), kuriuo naudojosi S. Hardmanas ir G. Talas, M. Nicholas, K. Y. Bjerkanas ir kt. Ši metodika, kuria ieškoma atsakymo, kas lèmé subjektų sprendimą pirkti elektromobilį, leidžia tiksliau suprasti vartotojų poreikị ir elgseną. Mokslinejje literatūroje galima rasti informacijos, kad ši metodika, deja, susiduria su respondentų šališkumo problema [4].

Dar vienas iš metodų - kokybinè diskusija (angl. qualitative discussion). Pavyzdžiui, S. Bakkeris ir J. J. Tripas atliko skatinimo priemonių tyrimą, organizuodami ekspertų dirbtuves, kuriose buvo diskutuojama apie miestams tinkančias iniciatyvas. Skatinimo priemonès buvo skirstomos pagal efektyvumo, veiksmingumo ir igyvendinamumo kriterijus [57]. Kokybinès diskusijos metodiką vertindami elektromobilių skatinimo priemones taike S. J. Skerlosas ir J. J. Winebrake'as, B. Holtsmarkas ir A. Skonhoftas, X. Zhangas ir kt., M. A. Aasnesas ir F. M. Aarestrupas, A. Ajanovicas ir R. Haasas, J. Kesteris ir kt. tyrèjai.

Kiti skatinimo priemonių tyrimo būdai. Vienas iš būdų elektromobilių skatinimo priemonems ir jų igyvendinimui vertinti yra mokslinès literatūros apžvalga. Šiuo metodu tyrimus atliko M. Ahmanas, E. H. Greenas ir kt., J. R. DeShazo'as, X. Zhangas ir X. Bai'as, $\mathrm{X}$. Zhangas ir kt. Tarp skatinimo priemonių analizès metodų galima išskirti ir daugiasluoksnę perspektyvą (angl. multi-layer perspective), kurią naudojo M. Nilssonas ir B. Nykvistas. Remiantis šia metodika, sociotechnologinèje sistemoje identifikuojama valdžios veiksmų įtaka elektromobilių proveržio scenarijui. Remiantis barjerų ir plètros veiksnių charakteristika skirtinguose lygiuose identifikuojamos reikalingos finansinès ir nefinansinès skatinimo intervencijos [64]. Retai straipsniuose sutinkamas, tačiau perèjimo prie elektromobiliu, pasitelkiant fiskalines paskatas, vertinimui tinkamas metodas - dinaminis modeliavimas (angl. dynamic simulation modelling). Šị metodą E. Shafiei’as ir kt. apjungè su integruotu energijos-transporto sistemos technologiju ir transporto priemoniu parko modeliavimu. Modelis naudojamas scenarijų analizei, itraukiant pagrindinius fiskalinius parametrus, iskaitant îvairius mokesčius ir subsidijas transporto priemonèms ir kuro kaštų mažinimui [65].

Kitas elektromobilių skatinimo sistemai analizuoti plačiai naudotas būdas yra agentais grịstas modelis (angl. agent-based model). Agentu modeliai gali būti nuo abstrakčių teorijos plètros modelių iki faksimilinių modelių (angl. facsimile models), kuriais siekiama numatyti konkrečius rezultatus. Faksimiliniai modeliai naudoja „realaus pasaulio“ aplinką, dažnai importuojamą iš 
geografinès informacijos sistemų, ir atitinka faktinę topografiją. Dirbtinè aplinka supaprastina konteksto vaizdavimą ir dažniausiai naudojama, kai pagrindinis demesys skiriamas elgsenos taisyklèms, o ne tam tikros ekosistemos dinamikai [66]. Plačiai paplitusị agentais grịstą modelị savo tyrimuose vertinant ịvairių tipų elektromobilių skatinimo sistemas naudojo M. G. Muelleris ir P. Haanas, J. M. Eppsteinas ir kt., C. Silvia ir
R. M. Krause'as, A. Adepetu'as ir kt., X. Sunas ir kt. Agentais grịsti modeliai grindžiami pakartotine autonominių ir nevienalyčių subjektų ar agentų sąveika, kai kiekvienas priima sprendimus pagal tam tikrą nustatytų taisyklių rinkinị. Šie agentai skiriasi vienas nuo kito demografiniais rodikliais, svarbiomis savybėmis, ịskaitant požiūrị $\mathfrak{i}$ technologijas ir aplinką, reagavimą $\mathfrak{i}$ informaciją [67].

4 lentelè. Alternatyvūs elektromobilių naudojimo skatinimo priemonių efektyvumo tyrimai (sudaryta straipsnio autorių

\begin{tabular}{|c|c|c|c|c|c|}
\hline \multicolumn{2}{|c|}{ Autorius } & Metodai & Regionas & Automobilio rūšis & $\begin{array}{l}\text { Nagrinèti } \\
\text { skatinimo } \\
\text { priemonių tipai }\end{array}$ \\
\hline $\begin{array}{l}\text { Adepetu } \\
\text { ir kt. }\end{array}$ & {$[68]$} & Agentais gristas modelis & $\begin{array}{c}\text { San } \\
\text { Franciskas, } \\
\text { JAV }\end{array}$ & Elektromobiliai & $\begin{array}{l}\text { Finansinès ir } \\
\text { nefinansinès } \\
\text { priemonès }\end{array}$ \\
\hline $\begin{array}{l}\text { Eppstein } \\
\text { ir kt. }\end{array}$ & {$[69]$} & Agentais grįstas modelis & JAV & $\begin{array}{c}\text { Iš išorès ịkraunami hibridiniai } \\
\text { elektromobiliai }\end{array}$ & $\begin{array}{l}\text { Finansinès } \\
\text { priemonès }\end{array}$ \\
\hline Sun ir kt. & [67] & Agentais gristas modelis & JAV & Elektromobiliai & Subsidijos \\
\hline $\begin{array}{l}\text { Silvia ir } \\
\text { Krause }\end{array}$ & {$[70]$} & Agentais grịstas modelis & JAV & $\begin{array}{c}\text { Elektromobiliai su } \\
\text { akumuliatoriais, iš išorès } \\
\text { ¿kraunami hibridiniai } \\
\text { elektromobiliai }\end{array}$ & $\begin{array}{l}\text { Finansinès ir } \\
\text { nefinansinès } \\
\text { priemonès }\end{array}$ \\
\hline $\begin{array}{l}\text { Mueller ir } \\
\text { Haan }\end{array}$ & {$[71]$} & $\begin{array}{c}\text { Agentais grįstas } \\
\text { modelis / Individualių } \\
\text { sprendimų procesų modelis }\end{array}$ & Šveicarija & Nauji keleiviniai automobiliai & $\begin{array}{l}\text { Finansinès ir } \\
\text { nefinansinès } \\
\text { priemonès }\end{array}$ \\
\hline $\begin{array}{c}\text { Shafiei ir } \\
\text { kt. }\end{array}$ & {$[65]$} & Dinaminis modeliavimas & Islandija & Elektromobiliai & $\begin{array}{l}\text { Finansinès } \\
\text { priemonès }\end{array}$ \\
\hline $\begin{array}{l}\text { Higgins } \\
\text { ir kt. }\end{array}$ & {$[72]$} & $\begin{array}{c}\text { Inovacijų difuzijos } \\
\text { modelis / Pasirinkimo } \\
\text { modeliavimas / } \\
\text { Daugiakriterinė analizė }\end{array}$ & Australija & Elektromobiliai & $\begin{array}{l}\text { Finansinès ir } \\
\text { nefinansinès } \\
\text { priemonès }\end{array}$ \\
\hline $\begin{array}{c}\text { Green ir } \\
\text { kt. }\end{array}$ & [73] & Literatūros apžvalga & JAV & $\begin{array}{c}\text { Elektromobiliai su } \\
\text { akumuliatoriais, iš išorès } \\
\text { ikraunami hibridiniai } \\
\text { elektromobiliai }\end{array}$ & $\begin{array}{l}\text { Finansinès } \\
\text { priemonès }\end{array}$ \\
\hline DeShazo & {$[74]$} & Literatūros apžvalga & $\begin{array}{l}\text { Kalifornija, } \\
\text { JAV }\end{array}$ & $\begin{array}{c}\text { Elektromobiliai su } \\
\text { akumuliatoriais, iš išorès } \\
\text { ¡kraunami hibridiniai } \\
\text { elektromobiliai }\end{array}$ & $\begin{array}{l}\text { Finansinès } \\
\text { priemonès }\end{array}$ \\
\hline $\begin{array}{c}\text { Zhang ir } \\
\text { kt. }\end{array}$ & {$[75]$} & Literatūros apžvalga & Kinija & Elektromobiliai & $\begin{array}{l}\text { Finansinès ir } \\
\text { nefinansinès } \\
\text { priemonès }\end{array}$ \\
\hline $\begin{array}{l}\text { Hardman } \\
\text { ir kt. }\end{array}$ & {$[4]$} & Literatūros apžvalga & $\begin{array}{l}\text { Ivairios } \\
\text { šalys }\end{array}$ & $\begin{array}{l}\text { Iš išorès įkraunami } \\
\text { elektromobiliai }\end{array}$ & $\begin{array}{l}\text { Finansinès } \\
\text { priemonès }\end{array}$ \\
\hline $\begin{array}{l}\text { Zhang ir } \\
\text { Bai }\end{array}$ & [76] & Literatūros apžvalga & Kinija & Naujos energijos automobiliai & $\begin{array}{l}\text { Finansinès ir } \\
\text { nefinansinès } \\
\text { priemonès }\end{array}$ \\
\hline
\end{tabular}




\begin{tabular}{|c|c|c|c|c|c|}
\hline Autoriu & & Metodai & Regionas & Automobilio rūšis & $\begin{array}{c}\text { Nagrinėti } \\
\text { skatinimo } \\
\text { priemonių tipai }\end{array}$ \\
\hline Ahman & {$[77]$} & Literatūros apžvalga & Japonija & Elektromobiliai & $\begin{array}{c}\text { Finansinès ir } \\
\text { nefinansinès } \\
\text { priemonès }\end{array}$ \\
\hline $\begin{array}{l}\text { Nilsson ir } \\
\text { Nykvist }\end{array}$ & {$[64]$} & $\begin{array}{c}\text { Modeliavimas / } \\
\text { Daugiasluoksnė perspektyva }\end{array}$ & $\begin{array}{l}\text { Europos } \\
\text { šalys }\end{array}$ & $\begin{array}{l}\text { Elektromobiliai su } \\
\text { akumuliatoriais }\end{array}$ & $\begin{array}{c}\text { Finansinès ir } \\
\text { nefinansinès } \\
\text { priemonès }\end{array}$ \\
\hline
\end{tabular}

Agentai vadovaujasi tikslais, gali būti paveikti vienas kito, mokytis iš savo aplinkos ir prisitaikyti prie besikeičiančiu aplinkybių ir naujos informacijos. Sąveika tarp agentų ir jų aplinkos ši modelį išskiria iš kitų sisteminio modeliavimo metodų ir daro ji ypač tinkama metodika, kai norima ívertinti skirtingų skatinimo politikos scenarijų poveiki [66]. Pavyzdžiui, C. Silvia ir R. M. Krause’as, siekdami ištirti skatinimo politikos intervencijos poveiki, naudojo agentais grịstą modelị imituodami elektromobilių pirkimo elgseną. Tyrime atsižvelgta ị šiuos kintamuosius: ar asmuo yra naujos transporto priemonès rinkoje savininkas; ar asmuo gali ịsigyti elektromobilį; ar jo vairavimo ippročiai atitinka tokios transporto priemonès diapazoną; ar namų ūkyje yra antra transporto priemoné; ar namų ùkis turès finansinès naudos naudodamas elektromobiliz; ar asmuo vertina aplinką; ar yra novatorius ir ar susipažinęs su elektra varomų transportų priemonių technologija [70].

\section{ELEKTROMOBILIŲ NAUDOJIMO SKATINIMO PRIEMONIŲ VERTINIMO MODELIO KONCEPTUALIZAVIMAS}

Straipsnio autoriai atkreipia dèmeș i $i$ tai, kad nemaža dalis mokslininkų ị savo tyrimo modelį įtraukia keletą metodų. Pavyzdžiui, A. Jennas ir kt., kurie analizavo skatinimo politikos ittaką hibridinių elektromobiliu pardavimams JAV 2000-2010 m., ì savo tyrimo modeli ịtraukè panelinių duomenų regresijos modelị su fiksuotais efektais ir momentų metodą. J. H. M. Langbroekas ir kt. elektromobilių keleto politinių paskatų tyrimą atliko remdamiesi nurodyto pasirinkimo eksperimentu, taip pat buvo ištirta socialinių ir psichologinių veiksnių itaka, naudojant transteorinio pokyčių modelio ir apsaugos motyvacijos teorijos konstruktus [61]. T. Lie- veno modelis sukonstruotas iš trijų dalių: vartotojų preferencijos buvo tiriamos naudojant jungtinę analizę ir hierarchinį Bajeso metodą (angl. hierarchical Bayes method), o nustatyti vartotoju pasitenkinimą pasirinktas Kano metodas [51].

Siekiant ištirti skirtingą skatinimo priemonių veiksmingumą, A. Jenno ir kt. tyrimo struktūrą sudare trys dalys: apibendrintas modelis, žinių modelis (angl. knowledge model) ir modelis su priklausomo kintamojo vélinimais. Pirmasis modelis atskleidžia vidutini paskatų poveikį visoje šalyje. Žinių modelis apima vartotojų sąmoningumą, supratimą apie skatinimo priemones ir leidžia nustatyti paskatu efektyvumo heterogeniškumą skirtingose valstijose. Modelis su priklausomo kintamojo vèlinimais atskleidžia svarbius ekonometrinių modelių endogeniškumo kriterijus [31]. A. Higginsas ir kt. prognozavo elektromobiliu naudojimo Australijoje plètrą iki 2030 metų. I savo kompleksinị modeli, kuris padejo ịvertinti technologijų pasirinkimą konkrečioje teritorijoje atsižvelgiant $\mathfrak{i}$ vartotojų heterogeniškumą, apjunge tris elementus: inovacijų difuzijos modeli (angl. innovative diffusion model), daugiakriterinę analizę ir pasirinkimo modeliavimą [72]. M. G. Muelleris ir P. Haanas taike dviejų pakopų individualių sprendimų procesų modeli, kuris naudingas vertinant politiką, darančią įtaką individualiems naujų lengvųjų automobilių pirkimo sprendimams. Pirmame etape individualiu pasirinkimų rinkiniai sudaromi naudojant paprastas, nekompensuojančias taisykles, pagrịstas anksčiau turètomis mašinomis. Antra, sprendimų priemejjai ịvertina alternatyvas pagal savo individualų pasirinkimą, naudodamiesi daugialypès svertinès vertès taisykle (angl. multi-attributive weighting rule). Šiame tyrime atributų svoriai nustatyti naudojant polinominị logit modelị [71]. 
Mokslineje literatūroje galima rasti ir daugiau unikalių modelių elektromobilių naudojimo skatinimo politikai analizuoti. Šio straipsnio autorių nuomone, kompleksinių modelių kūrimas padeda įvertinti skatinimo priemonių efektyvumą ịvairiais aspektais, ịvairiapusiškai ištirti ar palyginti skirtingais metodais gautus rezultatus. Straipsnio autoriai, išanalizavę elektromobilių skatinimo priemonių vertinimo praktiką, aprašytą moksliniuose leidiniuose, pateikia savo vertinimo modeli.

Šalyse, kur švarių automobilių skatinimo politika turi ilgametę patirtí, konkrečių priemonių vertinimą galima atlikti analizuojant statistinę analizę. Tačiau tokia tyrimo kryptis netinka valstybems, kurios visai neturi arba turi tik visapusiškos elektromobilių skatinimo politikos užuomazgas. Dèl šios priežasties siekiant sukurti vertinimo modelĭ, autorių nuomone, būtina analizuoti ir hipotetines skatinimo priemones, kurios šiuo metu nèra naudojamos tiriamoje šalyje, tačiau gali turèti reikšmingą poveikị elektromobilių plètrai. Esamų ir hipotetinių priemonių rinkiniai gali būti analizuojami vertinant vartotojų preferencijas, įtraukiant vieną iš pasirengimo mokèti metodikų $[49,50]$. Hipotetinių priemonių vertèms nustatyti galima apklausti vartotojus arba remtis ekspertų nuomone [51,78].
Skatinimo sistemos efektyvumą parodo ne tik vartotoju preferencijos. Pasak J. Lawo, efektyvumas matuojamas, kaip sèkmingai pasiekiama norimų rezultatų [79]. Šio straipsnio autorių nuomone, norint visapusiškai įvertinti, ar skatinimo priemonès yra efektyvios, reikia kompleksinio vertinimo, todèl ị vieną modelį reikia įtraukti skirtingus metodus. Vartotojų preferencijos tyrimą reikia papildyti igyvendinamumo, veiksmingumo ir kaštų analize, kuri parodo, kiek konkrečios priemonès (esamos ar hipotetinès) igyvendinimas kainuoja. Priemonių igyvendinamumas atskleidžia, kaip sudètinga igyvendinti skatinimo priemonę politiniu ir administraciniu lygiu [57]. Priemonių veiksmingumo vertinimas parodo, kurios iš priemoniu gali labiau prisidèti prie elektromobilių naudojimo plettros [80]. Tiek igyvendinamumas, tiek veiksmingumas gali būti tiriami kokybinès apklausos pagrindu ittraukiant ekspertus [57]. Gavus vartotojų preferencijų tyrimo, veiksmingumo, igyvendinamumo ir kaštu analizès rezultatus, šiems keturiems tyrimo blokams turi būti nustatomas vertinimo kriterijų svoris. Rekomenduotina, kad šiuos svorius nustatytų ekspertai, kurie gali objektyviau ịvertinti elektromobilių skatinimo aplinką, ìvairius plètros veiksnius ir barjerus. Šio straipsnio autorių siūlomą modelį užbaigia daugiakriterinis vertinimas,

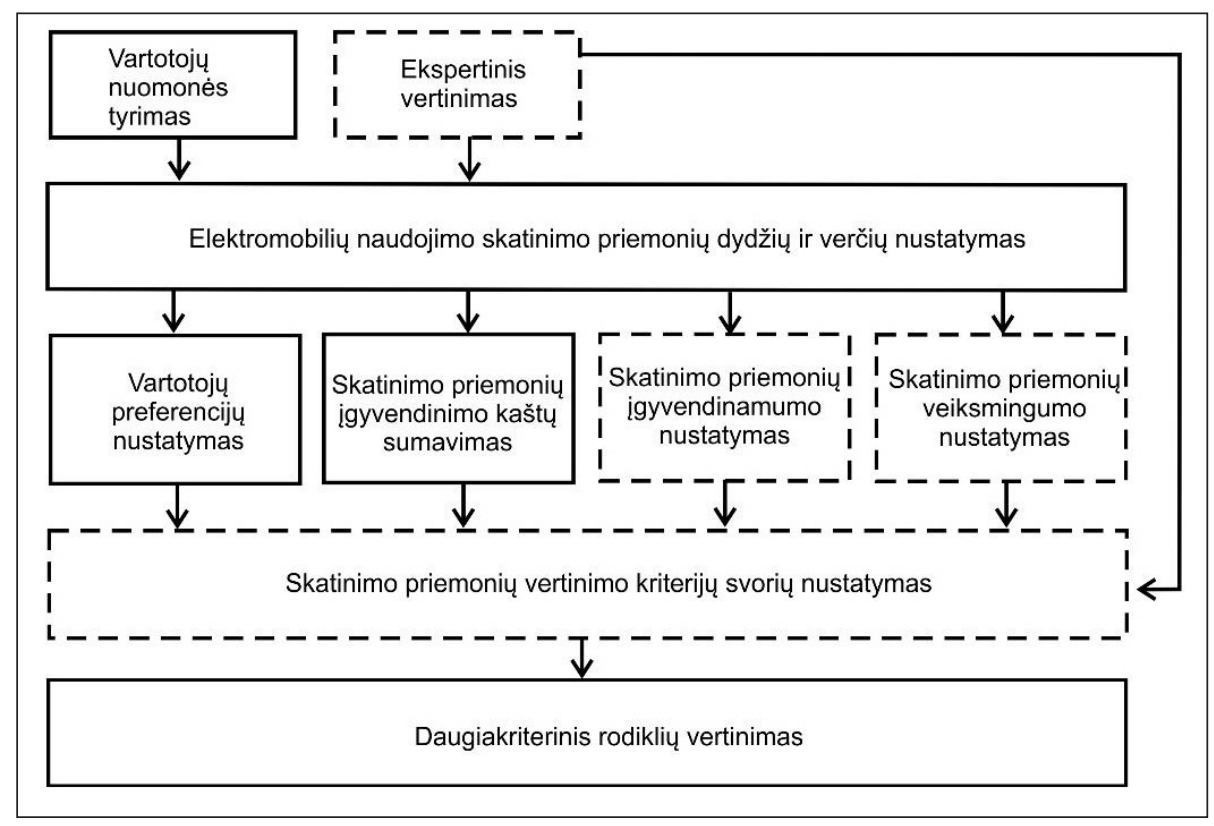

2 pav. Elektromobilių naudojimo skatinimo priemonių vertinimo modelis (sudarytas straipsnio autorių) 
kuriame apibendrinami visų tyrimo blokų rezultatai atsižvelgiant ị vertinimo kriterijų svorius.

\section{IŠVADOS}

Straipsnio autoriai išanalizavo mokslinèje literatūroje elektromobilių panaudojimo plètrą skatinančių priemonių efektyvumo vertinimo praktiką, apibendrino agreguoto ir disagreguotų duomenų naudojimą analizèse. Pasiūlyta vertinimo metodikas klasifikuoti $\mathfrak{i}$ tris grupes: statistine analize paremtus tyrimus, apklausomis paremtus tyrimus ir kitus skatinimo priemonių tyrimo būdus. Šalyse, kur švarių automobilių skatinimo politika turi ilgametę patirtị, konkrečių priemonių vertinimą galima atlikti analizuojant statistinę analizę. Tokių tyrimų metodologiją sudaro įvairių tipų regresijos. Tačiau tokia tyrimo kryptis netinka valstybèms, kurios visai neturi arba turi tik visapusiškos skatinimo politikos užuomazgas.

Elektromobilių panaudojimo plètrą skatinančių priemonių efektyvumo tyrimuose, paremtuose apklausomis, dažniausiai analizuojamas vartotojų pasirengimas mokèti. Pagrindiniai būdai ịvertinti vartotojų pasirengimą mokèti: naudoti nustatytų ir pareikštų preferencijų metodus. Diskretaus pasirinkimo modeliai yra dažniausiai sutinkami mokslinèje literatūroje, kuri analizuoja skatinimo priemonių efektyvumą. Tarp kitų elektromobilių panaudojimą skatinančių priemonių vertinimo būdų galima išskirti šiuos metodus: agentais grịstas modelis, dinaminis modeliavimas, daugiasluoksnè perspektyva, inovacijų difuzijos modelis ir literatūros apžvalga.

Nemaža dalis mokslininkų ị savo tyrimo modelị ịtraukia keletą metodų. Kompleksinių modelių kūrimas padeda ịvertinti skatinimo priemonių efektyvumą ịvairiais aspektais, ịvairiapusiškai ištirti ar palyginti skirtingais metodais gautus rezultatus. Straipsnio autoriai, remdamiesi išanalizuota praktika, konceptualizavo skatinimo priemonių efektyvumo vertinimo modeli. Remiantis šiuo modeliu siūloma analizuoti ir hipotetines skatinimo priemones, kurios šiuo metu nèra naudojamos tiriamoje šalyje, tačiau gali turèti reikšmingą poveikị elektromobilių plètrai. Siūlomo modelio pagrindą sudaro preferencijų tyrimas.

Straipsnio autorių nuomone, norint visapusiškai ịvertinti, ar skatinimo priemonès yra efek- tyvios, reikia kompleksinio vertinimo, todèl $\mathfrak{i}$ vieną modelị būtina ịtraukti skirtingus metodus. Vartotojų preferencijos tyrimas papildytas igyvendinamumo, veiksmingumo ir kaštų analize, kuri parodo, kiek konkrečios priemonès (esamos ar hipotetinès) igyvendinimas kainuoja. Gavus vartotojų preferencijų tyrimo, veiksmingumo, igyvendinamumo bei kaštų analizès rezultatus, šiems keturiems tyrimo blokams turi būti nustatomas vertinimo kriterijų svoris. Rekomenduotina, kad šiuos svorius nustatytų ekspertai, kurie gali objektyviau ịvertinti elektromobiliu skatinimo aplinką, i̇vairius plètros veiksnius ir barjerus. Šio straipsnio autorių siūlomą modelị užbaigia daugiakriterinis vertinimas, kuriame apibendrinami visų tyrimo blokų rezultatai atsižvelgiant ị vertinimo kriterijų svorius.

Gauta 20190515 Priimta 20191205

Literatūra

1. Windisch E. Driving Electric? A Financial Analysis of Electric Vehicle Policies in France. Statistical Finance. Ecole des Ponts ParisTech, 2013. https://tel. archives-ouvertes.fr/tel-00957749

2. Daina N., Sivakumar A., Polak W. J. Modelling electric vehicles use: a survey on the methods. Renewable \& Sustainable Energy Reviews. 2017. Vol. 68. P. 447-460.

3. Malmgren I. Quantifying the societal benefits of electric vehicles. World Electric Vehicle Journal. 2016. Vol. 8. P. 2032-6653.

4. Hardman S., Chandan A., Tal G., Turrentine T. The effectiveness of financial purchase incentives for battery electric vehicles - A review of the evidence. Renewable and Sustainable Energy Reviews. 2017. Vol. 80. P. 1100-1111.

5. Kley F., Wietschel M., Dallinger D. Evaluation of European Electric Vehicle Support Schemes. Working Paper Sustainability and Innovation, No. S7/2010. https://hdl.handle.net/10419/40019

6. Yang Z., Slowik P., Lutsey N., Searle S. Principles for Effective Electric Vehicle Incentive Design. Washington, DC: International Council on Clean Transportation, 2016. https://www.theicct.org/ sites/default/files/publications/ICCT_IZEV-incentives-comp_201606.pdf 
7. Mačiulis P., Konstantinavičiūtè I., Pilinkienė V. Assessment of electric vehicles promotion measures at the national and local administrative levels. Engineering Economics. 2018. Vol. 29. No. 4. P. 434-445.

8. Hanley C. Going Green: How Local Authorities Can Encourage the Take-up of Lower-carbon Vehicles. Royal Automobile Club Foundation, 2011. https://www.racfoundation.org/wp-content/uploads/2017/11/61442_racf_lcv-and-la-powersauthor-buchanan_aw.2_web.pdf

9. Hall D., Moultak M., Lutsey N. Electric Vehicle Capitals of the World: Demonstrating the Path to Electric Drive. Washington, DC: International Council on Clean Transportation, 2017. https://www. theicct.org/sites/default/files/publications/Global-EV-Capitals_White-Paper_06032017_vF.pdf

10. Rogers E. M. Diffusion of Innovations. 5th ed. New York: Free Press, 2003.

11. Wang N., Pan H., Zheng W. Assessment of the incentives on electric vehicle promotion in China. Transportation Research Part A: Policy and Practice. 2017. Vol. 101. P. 177-189.

12. Wang S., Li J., Zhao D. The impact of policy measures on consumer intention to adopt electric vehicles: Evidence from China. Transportation Research Part A: Policy and Practice. 2017. Vol. 105. P. 14-26.

13. Alhulail I., Takeuchi K. Effects of Tax Incentives on Sales of Eco-friendly Vehicles: Evidence from Japan. Discussion Paper No. 1412. Graduate School of Economics, Kobe University, 2014.

14. Ramos-Real F. J., Ramírez-Díazb A., Gustavo A., Marrerob G. A., Perez Y. Willingness to pay for electric vehicles in Island regions: The case of Tenerife (Canary Islands). Renewable \& Sustainable Energy Reviews. 2018. Vol. 98. P. 140-149.

15. Mersky A. C., Sprei F., Samaras C., Qian Z. S. Effectiveness of incentives on electric vehicle adoption in Norway. Transportation Research Part D: Transport and Environment. 2016. Vol. 46. P. 56-68.

16. Axsen J., Kurani K. Hybrid, plug-in hybrid, or electric - What do car buyers want? Energy Policy. 2013. Vol. 61. P. 532-543.

17. Sierzchula W., Bakker S., Maat K., Wee B. The influence of financial incentives and other socio-economic factors on electric vehicle adoption. Energy Policy. 2014. Vol. 68. P. 183-194.
18. Diamond D. The impact of government incentives for hybrid-electric vehicles: evidence from US states. Energy Policy. 2009. Vol. 37. No. 3. P. 972-983.

19. Münzel C., Plötz P., Sprei F., Gnann T. How large is the effect of financial incentives on electric vehicle sales? - A global review and European analysis. Energy Economics. 2019. Vol. 84. 104493.

20. Shewmake S., Jarvis L. Hybrid cars and HOV lanes. Transportation Research Part A: Policy and Practice. 2014. Vol. 67. P. 304-319.

21. Vergis S., Chen B. Comparison of plug-in electric vehicle adoption in the United States: a state by state approach. Research in Transportation Economics. 2015. Vol. 52. P. 56-64.

22. Verbeek M. A. Guide to Modern Econometrics. 4th ed. Wiley, 2015.

23. Qiua Y. Q., Zhou P., Sun H. C. Assessing the effectiveness of city-level electric vehicle policies in China. Energy Policy. 2019. Vol. 130. P. 22-31.

24. Javid J. R., Nejat A. A comprehensive model of regional electric vehicle adoption and penetration. Transport Policy. 2017. Vol. 54. P. 30-42.

25. Ma S., Fan Y., Feng L. An evaluation of government incentives for new energy vehicles in China focusing on vehicle purchasing restrictions. Energy Policy. 2017. Vol. 110. P. 609-618.

26. Wee S., Coffman M., La Croix S. Do electric vehicle incentives matter? Evidence from the 50 US states. Research Policy. 2018. Vol. 47. No. 9. P. 1601-1610.

27. Chandra A., Gulati S., Kandlikar M. Green drivers or free riders? An analysis of tax rebates for hybrid vehicles. Journal of Environmental Economics and Management. 2010. Vol. 60. P. 78-93.

28. Jenn A., Azevedo I. L., Ferreira P. The impact of federal incentives on the adoption of hybrid electric vehicles in the United States. Energy Economics. 2013. Vol. 40. P. 936-942.

29. Gallagher K. S., Muehlegger E. Giving green to get green? Incentives and consumer adoption of hybrid vehicle technology. Journal of Environmental Economics and Management. 2011. Vol. 61. No. 1. P. 1-15.

30. Li S., Tong L., Xing J., Zhou Y. The market for electric vehicles: indirect network effects and policy design. Journal of the Association of Environmental 
and Resource Economists. 2017. Vol. 4. No. 1. P. 89-133.

31. Jenn A., Springel K., Gopal A. R. Effectiveness of electric vehicle incentives in the United States. Energy Policy. 2018. Vol. 119. P. 349-356.

32. Štreimikienè D., Ališauskaitè-Šeškienė I. Lietuvos gyventojų pasirengimo mokèti už atsinaujinančius energijos išteklius vertinimas. Energetika. 2014. T. 60. Nr. 3. P. 169-183.

33. Breidert C., Hahsler M., Reutterer T. A review of methods for measuring willingness-to-pay. Innovative Marketing. 2006. Vol. 2. No. 4.

34. Lieven T., Mühlmeier S., Henkel S., Waller F. J. Who will buy electric cars? An empirical study in Germany. Transportation Research Part D. 2011. Vol. 16. P. 236-243.

35. Green P. E., Srinivasan V. Conjoint analysis in consumer research: issues and outlook. Journal of Consumer Research. 1978. Vol. 5. No. 2. P. 103123.

36. Train K. E. Discrete Choice Methods with Simulation. 2nd ed. Cambridge University Press, 2009.

37. Liao F., Molin E., van Wee B. Consumer preferences for electric vehicles: a literature review. Transport Reviews: A Transnational, Transdisciplinary Journal. 2017. Vol. 37. No. 3. P. 252-275.

38. Ma S., Xu J. H., Fan Y. Willingness to pay and preferences for alternative incentives to EV purchase subsidies: An empirical study in China. Energy Economics. 2019. Vol. 81. P. 197-215.

39. Krupa J. E., Rizzo D. M., Eppstein M. J., Lanute D. B., Gaalema D. E., Lakkaraju K., Warrender C. E. Analysis of a consumer survey on plugin hybrid PEVs. Transportation Research Part A: Policy and Practice. 2014. Vol. 64. P. 14-31.

40. Larson D., Viáfara J., Parons R. V., Elias A. Consumer attitudes about electric cars: Pricing analysis and policy implications. Transportation Research Part A: Policy and Practice. 2014. Vol. 69. P. 299-314.

41. Krause R. M., Carley S. R., Lane B. W., Graham J. D. Perception and reality: Public knowledge of plug-in electric vehicles in 21 U.S. cities. Energy Policy. 2013. Vol. 63. P. 433-40.

42. Hardman S., Tal G. Exploring the decision to adopt a high-end battery electric vehicle: the role of financial and non-financial motivations. Transportation Research Record: Journal of the Trans- portation Research Board. 2016. Vol. 2572. No. 1. P. 20-27.

43. Bjerkan K. Y., Nørbech T. E., Nordtømme M. E. Incentives for promoting Battery Electric Vehicle (BEV) adoption in Norway. Transportation Research Part D: Transport and Environment. 2016. Vol. 43. P. 169-80.

44. Tal G., Nicholas M. Exploring the impact of the federal tax credit on the plug-in vehicle market. Transportation Research Record: Journal of the Transportation Research Board. 2016. Vol. 2572. No. 1. P. 95-102.

45. Sánchez-Braza A., Cansino J. M., Lerma E. Main drivers for local tax incentives to promote electric vehicles: The Spanish case. Transport Policy. 2014. Vol. 36. P. 1-9.

46. Qian L., Soopramanien D. Heterogeneous consumer preferences for alternative fuel cars in China. Transportation Research Part D. 2011. Vol. 16. P. 607-613.

47. Hackbarth A., Madlener R. Consumer preferences for alternative fuel vehicles: a discrete choice analysis. Transportation Research Part D. 2013. Vol. 25. P. 5-17.

48. Ewing G., Sarigollu E. Car fuel-type choice under travel demand management and economic incentives. Transport Research D. 1998. Vol. 3. No. 6. P. 429-444.

49. Lee Y., Kim C., Shin J. A hybrid electric vehicle market penetration model to identify the best policy mix: a consumer ownership cycle approach. Applied Energy. 2016. Vol. 184. P. 438-449.

50. Helveston J. P., Liu Y., McDonnell Feit E., Fuchs E., Klampfl E., Michalek J. J. Will subsidies drive electric vehicle adoption? Measuring consumer preferences in the U.S. and China. Transportation Research Part A. 2015. Vol. 73. P. 96-112.

51. Lieven T. Policy measures to promote electric mobility - A global perspective. Transportation Research Part A. 2015. Vol. 82. P. 78-93.

52. Skerlos S. J., Winebrake J. J. Targeting plug-in hybrid electric vehicle policies to increase social benefits. Energy Policy. 2010. Vol. 38. P. 705-708.

53. Zhang X., Xie J., Rao R., Liang Y. Policy incentives for the adoption of electric vehicles across countries. Sustainability. 2014. Vol. 6. P. 8056-8078.

54. Aasness M. A., Odeck J. The increase of electric vehicle usage in Norway incentives and adverse 
effects. European Transport Research Review. 2015. Vol. 7. No. 4.

55. Holtsmark B., Skonhoft A. The Norwegian support and subsidy policy of electric cars. Should it be adopted by other countries? Environmental Science \& Policy. 2014. Vol. 42. P. 160-168.

56. Ajanovic A., Haas R. Dissemination of electric vehicles in urban areas: major factors for success. Energy. 2016. Vol. 115. P. 1451-1458.

57. Bakker S., Trip J. J. Policy options to support the adoption of electric vehicles in the urban environment. Transportation Research Part D. 2013. Vol. 25. P. 18-23.

58. Kester J., Noel L., Zarazua de Rubens G., Sovacool B. S. Policy mechanisms to accelerate electric vehicle adoption: A qualitative review from the Nordic region. Renewable and Sustainable Energy Reviews. 2018. Vol. 94. P. 719-731.

59. Sheldon T. L., Dua R. Measuring the cost-effectiveness of electric vehicle subsidies. Energy Economics. 2019. Vol. 84. 104545.

60. Dumortier J., Siddiki S., Carley S., Cisney J., Krause R. M., Lane B. W., Rupp J. A., Grahamb J. D. Effects of providing total cost of ownership information on consumers' intent to purchase a hybrid or plug-in electric vehicle. Transportation Research Part A. 2015. Vol. 72. P. 71-86.

61. Langbroek J. H. M., Franklin J. P., Susilo Y. O. The effect of policy incentives on electric vehicle adoption. Energy Policy. 2016. Vol. 94. P. 94-103.

62. Potoglou D., Kanaroglou P. S. Household demand and willingness to pay for clean vehicles. Transportation Research Part D. 2007. Vol. 12. P. 264274.

63. Qian L., Grisolía J. M., Soopramanien D. The impact of service and government-policy attributes on consumer preferences for electric vehicles in China. Transportation Research Part A: Policy and Practice. 2019. Vol. 122. P. 70-84.

64. Nilsson M., Nykvist B. Governing the electric vehicle transition - Near term interventions to support a green energy economy. Applied Energy. 2015. Vol. 179. P. 1360-1371.

65. Shafiei E., Davidsdottira B., Fazelia R., Leaverb J., Stefanssonc H., Asgeirssonc E. I. Macroeconomic effects of fiscal incentives to promote electric vehicles in Iceland: Implications for government and consumer costs. Energy Policy. 2018. Vol. 114. P. 431-443.

66. McLane A. J., Semeniuk C., McDermid G. J., Marceau D. J. The role of agent-based models in wild life ecology and management. Ecological Modelling. 2011. Vol. 222. No. 8. P. 1544-1556.

67. Sun X., Liu X., Wang Y., Yuan F. The effects of public subsidies on emerging industry: An agentbased model of the electric vehicle industry. Technological Forecasting and Social Change. 2019. Vol. 140. P. 281-295.

68. Adepetu A., Keshav S., Arya V. An agent-based electric vehicle ecosystem model: San Francisco case study. Transport Policy. 2016. Vol. 46. P. 109-122.

69. Eppstein J. M., Grover K. D., Marshall S. J., Rizzo M. D. An agent-based model to study market penetration of plug-in hybrid electric vehicles. Energy Policy. Vol. 39. No. 6. P. 3789-3802.

70. Silvia C., Krause R. M. Assessing the impact of policy interventions on the adoption of plug-in electric vehicles: An agent-based model. Energy Policy. 2016. Vol. 96. P. 105-118.

71. Mueller M. G., Haan P. How much do incentives affect car purchase? Agent-based microsimulation of consumer choice of new cars - Part I: Model structure, simulation of bounded rationality, and model validation. Energy Policy. 2009. Vol. 37. P. 1072-1082.

72. Higgins A., Paevere P., Gardner J., Quezada J. Combining choice modelling and multi-criteria analysis for technology diffusion: An application to the uptake of electric vehicles. Technological Forecasting \& Social Change. 2012. Vol. 79. P. 1399-1412.

73. Green E. H., Skerlos S. J., Winebrake J. J. Increasing electric vehicle policy efficiency and effectiveness by reducing mainstream market bias. Energy Policy. 2014. Vol. 65. P. 562-6.

74. DeShazo J. R. Improving incentives for clean vehicle purchases in the United States: challenges and opportunities. Review of Environmental Economics and Policy. 2016. Vol. 10. No. 1. P. 149-65.

75. Zhang X., Liang Y., Yu E., Rao R., Xie J. Review of electric vehicle policies in China: content summary and effect analysis. Renewable \& Sustainable Energy Reviews. 2017. Vol. 70. P. 698-714. 
76. Zhang X., Bai X. Incentive policies from 2006 to 2016 and new energy vehicle adoption in 20102020 in China. Renewable \& Sustainable Energy Reviews. 2017. Vol. 70. P. 24-43.

77. Ahman M. Government policy and the development of electric vehicles in Japan. Energy Policy. 2006. Vol. 34. P. 433-443.

78. Murphy J. J., Allen P. G., Stevens T. H., Weatherhead D. A meta-analysis of hypothetical bias in stated preference valuation. Environmental and Resource Economics. 2005. Vol. 30. P. 313-325.

79. Law J. A Dictionary of Business and Management. Oxford University Press, 2009.

80. Zhou Y., Levin T. E., Plotkin S. E. Plug-in Electric Vehicle Policy Effectiveness: Literature Review. Energy Systems Division, Argonne National Laboratory, 2016. https:/www.energy.gov/sites/prod/ files/2017/01/f34/PlugIn\%20Electric\%20Vehicle\%20Policy\%20Effectiveness\%20Literature $\% 20$ Review.pdf
Povilas Mačiulis, Inga Konstantinavičiūtè, Vaida Pilinkiené, Alina Stundžienè

\section{THE MODEL FOR ASSESSING}

THE EFFECTIVENESS OF ELECTRIC VEHICLE PROMOTION MEASURES

\section{Summary}

The transportation sector has a particularly strong impact on governments' efforts to achieve the objectives of decarbonisation. This is especially true for road transport, where the main challenge is to switch to clean vehicles, electric cars being the most popular ones. Despite the advantages and growing popularity of electric vehicles, the development of their use is hampered by the price which is higher than that of conventional cars driven on fossil fuels. All countries possess limited resources, which necessitates the determination of how particular results can be achieved with the lowest possible material and time costs. In all countries, the majority of the road vehicle fleet consists of privately owned cars. Therefore, the assessment of individual promotion measures calls for taking into account not only expert opinions and financial gains, but also consumer preferences that can appear to be the main barrier to the development of the use of new technologies. Scientific literature contains a variety of the methods for assessing promotion of the use of electric cars based on different methodologies or their combinations. Nevertheless, there is still a lack of a measure effectiveness assessment system that would fully summarize consumer preferences, feasibility and efficiency, and would consider the costs of implementing financial and non-financial promotion measures. The main purpose of this article is to research the practice of assessing electric vehicle promotion measures and conceptualize the model for assessing the effectiveness of electric vehicle promotion measures. The methods of the research include scientific literature analysis, systematization and comparative analysis.

Keywords: electric vehicle, effectiveness, promoting measures 